\title{
Malta and the study of Arabic in the sixteenth to the nineteenth centuries
}

\author{
Carmel Cassar*
}

\begin{abstract}
The Holy See became aware of the potential evangelising role of the Maltese in Ottoman lands at least from the mid-sixteenth century. This had much to do with Malta's geographical proximity to North Africa, coupled with the ability of the Maltese to speak a native Semitic language, believed to be close to Arabic, while at the same time being fervently Catholic Christians. Malta was singled out for this role mainly because the majority of Levantine Christian communities, then largely under Ottoman rule, were known to speak some form of Arabic. The combination of these factors appeared to be an excellent combination of circumstances to the Catholic Church authorities in Rome who believed that Malta was ideally suited for the teaching of Arabic. In Rome there was a general belief that the establishment of a school of Arabic in Malta, would help make the Catholic Church more accessible to the Christians of the Levant. However, despite continuous efforts, throughout the seventeenth and eighteenth centuries, by the Holy Congregation of Propaganda Fide, the teaching of Arabic never really took off in Malta. Under British colonial administration, in the early nineteenth century, Arabic remained on the list of subjects taught at the University of Malta and was later introduced at the Lyceum and the Valletta Government School. The British colonial authorities may even have encouraged its teaching and for a brief time, in the mid-nineteenth century, the well known Lebanese scholar Ahmad Faris al-Shidyaq, was lecturer of Arabic at Valletta. The end of Arabic teaching during World War One coincided with the emergence of the belief, pushed by Lord Gerald Strickland, that the Maltese descended from the Phoenicians. It was believed that the Maltese had preserved ancient Phoenician, rather than Arabic, over the millennia. By associating the Maltese with the ancient Phoenicians Strickland was simply saying that the Maltese might have had Semitic origins but that did not mean they were Arabs.
\end{abstract}

\section{Keywords}

Maltese missionaries, School of Arabic, Maltese language, the Levant, Levantine Christians, Propaganda Fide, Franciscans, Knights of Malta.

* Institute for Tourism, Travel \& Culture, University of Malta, Msida MSD 2080, Malta, carmel.cassar@um.edu.mt 


\section{Intellectual curiosity or an attempt at evangelisation?}

In a book published in Malta in 1843, the anonymous author felt duty-bound to explain:

Some years after the setting up of the Holy Congregation of Propaganda Fide [1622], the Holy See ordered the creation of a school of Arabic on the island of Malta. In order to provide the holder of this chair with an honorarium, the Bishop of Malta (induced by the said Holy Congregation) instituted the benefice called Tal-Isqof (literally 'of the Bishop') in 1637. This [benefice] was ordinarily conferred in Rome. In 1795 Pope Pius VI conceded a rescriptum [a Pope's official reply to an inquiry concerning a point of law or morality] to Grand Master De Rohan, which stipulated that the incumbent of the benefice had the duty to teach the Arabic language at the University of Studies of Malta. Over the last 20 years or so [1843], this chair was abolished due to a shortage of students. ${ }^{1}$

At the time of writing, the teaching of Arabic had been stopped for some time only to be re-launched a few years later. Yet it was evident that Arabic was bound to die a natural death. In reality, although Arabic had been taught in Malta since the early seventeenth century it never really took off. Interestingly, the nineteenth century statement above touches upon a topic that had been a cause of much debate for several centuries. This had much to do with Malta's geographical proximity to North Africa, coupled with the ability of the Maltese to speak a native Semitic language while at the same time being fervently Catholic Christians. Furthermore, the majority of Levantine Christian communities, then largely under Ottoman rule, were known to speak some form of Arabic. The combination of these factors appeared to be an excellent combination of circumstances to the Catholic Church authorities in Rome who believed that Malta was ideally suited for the teaching of Arabic. There was a general belief that the establishment of a school of Arabic in Malta, and encouraging the Maltese to learn that language would make the Catholic Church more accessible to the Christians of the Levant.

The Holy See became conscious of the potential evangelising role of the Maltese in Ottoman lands at least from the mid-sixteenth century. At that time Ignatius Loyola, founder of the Society of Jesus, had singled out Malta as a feasible centre for missionary activities directed to the Levant. But it was only during the rule of Pope Gregory XIII (1572-85) that Rome became convinced of the crucial role that could be played by Malta in this regard. Interest in Malta may probably be attributed to the excellent services rendered in

\footnotetext{
${ }^{1}$ Raccolta di varie cose antiche e moderne utili ed interessanti riguardanti Malta e Gozo (Malta: Giuseppe Camilleri \& Co., 1843), p. 140.
} 
Rome by Leonardo Abel, a Maltese canon and doctor of laws, later Bishop of Sidon, who was very knowledgeable in Arabic. Abel had spent some time as procurator for the deposed Syriac Patriarch of Antioch Ignatius Ni'matallah, ${ }^{2}$ and was later appointed as emissary to the Oriental churches by Pope Gregory XIII. Abel then spent four years, from 1583 to 1587, travelling in the Ottoman empire, through what are now Syria, Lebanon, Iraq and Egypt, although he returned to Rome with disappointing results. ${ }^{3}$

Abel's mission was rather unique. However, Abel did not exactly share his keen interest and solid knowledge of Arabic with other members of the Maltese educated elite. Indeed the Catholic authorities were soon to discover that the Maltese were more interested in learning Latin, Italian and other European languages rather than Arabic. As a result, despite some solid developments in the opening of a school of Arabic and Oriental languages, meant to teach potential missionaries to the Levant, Malta never really took off as a centre of great value for the study of Arabic.

Nonetheless, Rome continued to believe that Malta was a special place for Arabic, a view based on the assumption that the Maltese could communicate with Arabic speakers. The idea was so strongly entrenched that Pope Paul V (1605-21) expressly ordered the transfer of the Maltese Capuchin preacher, Friar Giovanni Maria, to Rome where he was to serve as confessor of

2 Leonardo Abel was procurator of the Syriac Patrirarch of Antioch, Ignatius Ni'matallah, (Latinized as Nehemias). Ni'matallah served as Patriarch from 1557 to 1576. His close collaboration with Pope Gregory XIII and attempts to unite his church with Rome led by the spring of 1576 to his forced abdication and exile. He travelled to Italy and sought refuge in Rome where he was interviewed about his intentions by Cardinal Giulio Antonio Santoro, protector of Oriental Christians, and three other experts, one of whom was Leonardo Abel who soon after entered into the service of the Patriarch thanks to his knowledge of Arabic. For his part Patriarch Ni'matallah was very knowledgeable in mathematics and astronomy, and Pope Gregory appointed him a member of the Commission for the Reform of the Calendar. Ni'matallah's involvement induced him to write a detailed report in which he proposed changes in the Julian Calendar which Leonardo Abel translated from Arabic to Latin. By the spring of 1581 Cardinal Santoro had proposed to the Pope to send Leonardo Abel as papal envoy to the Levant. In May of 1582, during an audience with Gregory XIII, Ni'matallah proposed sending a Catholic bishop who was well versed in Arabic to Syria to attend to other missions in the Levant. Abel was an obvious choice. But it took another two centuries for the Syriac Catholic Church to become formally and officially united with Rome in 1781, Levi della Vida, Giorgio, Documenti intorno alla relazioni delle Chiese Orientali con la Santa Sede durante il pontificato di Gregorio XIII, 'Studi e Testi' 92 (Vatican City, 1948), pp. 1-13, 20-32.

3 Leonardo Abel was consecrated titular bishop of Sidon. Abel's story can be found in Une mission religieuse en Orient au XVIe siècle, trans. Adolphe d'Avril (Paris: Mme ve B. Duprat, 1866); Levi della Vida, Documenti intorno alla relazioni delle Chiese Orientali, pp. 28-39; Frazee, Charles A., Catholics and Sultans. The Church and the Ottoman Empire 1453-1923 (Cambridge: Cambridge University Press, 1983), pp. 74-7. 
Arabic. Fra Giovanni Maria served as Arabic language confessor in Rome continuously for 18 months and was only allowed to return to Malta in September 1608 in order to carry on preaching and confessing in Malta. ${ }^{4}$

It would be fair to say that there was actually some real effort to make Malta a centre of Arabic teaching during those years. One may also argue that by the mid-seventeenth century some solid progress was achieved. However not much progress was registered in the following two centuries as Arabic was taught in a very casual manner and the classes remained very small, never exceeding ten students in number. By then the majority of students seem to have been interested in Arabic classes for pleasure, or curiosity. Despite attempts to encourage Maltese students, through the establishment of money prizes in the eighteenth century, the Congregation of Propaganda Fide in Rome did not succeed in convincing the Maltese educated elites to study Arabic.

\section{The uses of language}

There have been several attempts to analyze the role of the teaching of Arabic in Malta over the last few decades. A detailed comprehensive study on the subject was first published by Antonio Cremona, a man of letters and a founder member of Ghaqda tal-Kittieba tal-Malti (The Maltese Writers Society) in the early $1950 s^{5}$ The availability of previously inaccessible documents in the 1960s and 1970s induced Dionisius Agius to carry out more intense research on the school of Arabic. ${ }^{6}$ However, these two authors, both linguists, were primarily concerned with the teaching of Arabic to some extent as a precursor of the teaching of Maltese. Unlike previous studies, the present paper, largely based on the documentation found at the Congregation of Propaganda Fide in Rome, seeks to look at the teaching of Arabic from a different perspective. Primarily it intends to assess both the cultural role and the uses of Arabic as a tool for missionary activities in the Maghreb and the Ottoman lands. Secondly, it will try to evaluate the impact of changing circumstances in Malta throughout the long period of the rule of the Hospitaller

\footnotetext{
${ }^{4}$ Biblioteca Apostolica Vaticana [hereafter BAV], Barberiniani Latini [hereafter Barb. Lat.] vol. 6676, f.12-v.

5 Cremona, Antonio, "L'antica fondazione della scuola di lingua araba in Malta", Melita Historica, 1/2 (1953), pp. 87-103; 1/3 (1954), pp. 141-9; 1/4 (1955), pp. 207-20.

${ }^{6}$ Agius, Dionisius, Malta, Centru ghat-Taghlim ta' l-Gharbi fil-Mediterran (Seklu Sbatax sasSeklu Dsatax, (Malta: Klabb Kotba Maltin, 1980), translated into English and published as The Study of Arabic in Malta: 1632-1915 (Louvain: Peeters, 1990).
} 
Order of St John and the changing circumstances brought about by the advent of the British. It is thus necessary to look briefly at the role played by the uses of language throughout the long stretch of time from the sixteenth to the early twentieth centuries. Throughout this long period of history, Maltese was the unwritten language of the local community while the official language of communication in church, law courts and teaching was Tuscan Italian - a language that had originally been adopted by the Knights Hospitallers as their language of administration in $1530 .^{7}$ However, over the centuries, the Maltese were identified as native Arabic speakers. Undoubtedly the use of a peculiar and distinctive language of Semitic origins, like Maltese, was often concomitant with the notion of a culturally autonomous community that reinforced it further. Still, on account of its Semitic base, well into the nineteenth century, the Maltese language continued to function solely as a local dialect. Maltese held the same status as that of Italian dialects, while Italian froze into an official language on the same lines of Latin, useful for lyric, poetry and high culture, but unavailable to the majority of a society, still largely illiterate and economically backward. Nonetheless even as early as the sixteenth century the Catholic Church came to appreciate the potential of using Malta as a base for the study of Arabic with the intention of converting Muslims, or at least to bring the Christians of the Levant into closer union with Rome. ${ }^{8}$

The association of the Maltese people with Arabic, a language largely spoken by Muslims, did not go down well with the Maltese.' An 'Arabic dialect', in a Catholic frontier Mediterranean state, would have undoubtedly been associated with Islam. Nonetheless Francisco Nuñez Muley, a Morisco leader in sixteenth-century Spain, who protested against unfair treatment of the Arabic speaking conversos, declared that "the Egyptians, Syrians, Maltese and other Christian peoples speak, read and write in Arabic and are still Christian

7 Cassar, Carmel, Society, Culture and Identity in Early Modern Malta (Malta: Mireva Publications, 2000), esp. chapters 7-9; Brincat, Joseph M., "Languages in Malta and the Maltese language”, in Malta Roots of a Nation, ed. K. Gambin (Malta: Heritage Malta, 2004), pp. 213-24.

8 Borg, Alexander, "Language", in Malta Culture and Identity, ed. Henry Frendo and Oliver Friggieri (Malta: Ministry of Youth and the Arts, 1994), pp. 27-50; Cassar, Carmel, "Malta: language, literacy and identity in a Mediterranean island society', National Identities 3/3 (2001), pp. 257-75.

9 It has been argued that the Maltese people's lifestyle has been impressed forever by the arrival of St. Paul, since throughout his lifetime every Maltese hears the story of the saint's shipwreck on the island a number of times. The influence of this event has therefore assumed prime importance for the Maltese sense of identity as a separate community. See for example, SerracinoInglott, Peter, "Kattolicità Maltija: Jew il-Vokazzjoni tal-huttaba”, in L-Identità Kulturali tà Malta, ed. Toni Cortis (Malta: Department of Information, 1989), pp. 265-7. 
as we are". ${ }^{10}$ Probably Muley's declaration could have applied to the fifteenth century, but not to the sixteenth century when Malta had a crusading Order as feudal overlord whose raison d'être was to wage perpetual war against the omnipresent Muslim Turk.

It follows that the early modern idea of using Malta as a base to teach Arabic can be interpreted as a by-product of a combination of determinant factors. It had partly something to do with the geographical position of Malta in the central Mediterranean and was partly linked to the crusading role of an Order of Knights-cum-monks whose main role was the defence of Christendom from the Ottoman Muslim menace. Above all the idea coincided with Catholic Church policy in the sixteenth century - an issue that deserves to be seen in some detail.

\section{The Jesuits, the Maltese language, and the Levant}

This is the atmosphere which originally induced Ignatius Loyola (1491-1556), the founder of the Society of Jesus, to hang up his sword on an altar dedicated to the Virgin of Monserrat and commence his 'pilgrim's journey' to Jerusalem. Loyola had witnessed the final triumph of the Spaniards over the Moors in Spain and parts of North Africa. The experience must have left its mark, particularly since his early plan was to convert the Muslims, and re-Christianize North Africa and the Levant. ${ }^{11}$

Loyola soon realized Malta's great potential as a stepping stone for building contacts with the Muslim Maghreb. Thus in 1554 Loyola approved the joint request of Grand Master La Sengle and the Catalan Bishop of Malta Domenico Cubelles to establish a Jesuit college in Malta from where Jesuit missionaries could be trained for the Levant. ${ }^{12}$ It was even thought that a college in Malta

${ }^{10}$ Kamen, Henry, Inquisition and Society in Spain in the Sixteenth and Seventeenth Centuries (London: Weidenfeld and Nicolson, 1985), p. 108.

${ }^{11}$ In the early phase of his vocation, during the 1520 s and 1530 s, Ignatius Loyola was convinced that his true vocation was to travel to the Holy Land and to spend the rest of his life in devotion and penance in Jerusalem where he hoped he would be able to help others. O'Reilly, T., "Ignatius of Loyola and the Counter-Reformation: the hagiographic tradition", Heythrop Journal, 31 (1990), pp. 439-70, reproduced in O'Reilly, T., From Ignatius Loyola to St John of the Cross (Aldershot: Variorum, 1995), pp. 445-6.

12 In January 1554 Ignatius Loyola informed Father Paschasio (Broëtio) in Paris that he had promised Grand Master Claude de La Sengle (1553-57) and the Bishop to send some members of the Company to Malta and to Africa to the Moors in order to teach the Gospel of Christ, Monumenta Ignatiana. Epistolae ex autographis vel ex antiquioribus exemplis collecta, vol. VII (Madrid: G. López del Horno, 1908), letter 4073, p.188: 30 January, 1554. 
would serve as a better base for missionary activities in the Levant than Messina where a college had been set up in 1548. There were even plans to send one of the founding members of the Company, Father Bobadilla, to Malta. But a quarrel between the Grand Master and the Bishop of Malta induced the Jesuit authorities in Rome to temporarily shelve the Malta project. ${ }^{13}$ Why would someone like Ignatius Loyola have so much interest in Malta? It seems that the main reason was based on the fact that the Maltese spoke a Semitic language, close to Arabic, which in Loyola's view appeared similar to the language spoken in the Holy Lands. Despite the early interest and effort the Malta proposal was shelved indefinitely largely because of petty differences between the Grand Master and Bishop Cubelles. His fellow brethren could ill afford to wait until the power-holders of Malta had settled their petty differences and by December 1554 a college of Arabic was established in Rome. ${ }^{14}$ Hardly a generation passed before the Jesuits began to look at Malta again, probably influenced by the changing political circumstances that took place between the mid 1550s and the mid 1580s. Amongst the crucial changing circumstances one may mention that Spain lost most of its North African strongholds; Venice lost Cyprus, despite the Christian victory at Lepanto, leading to an abysmal decline of Venetian influence in Ottoman lands; and France gained more political prestige and economic preponderance in the lands of the Grand Turk.

By the 1580s, the Jesuits and the Holy See began to look for alternative ways to organize missionary activities among the Arabic speakers in North Africa and the Levant. Possibly the Jesuits may have realized that the Maltese spoke a language that was possibly, by that time, of little use in their plan to establish contact with Arabic-speaking populations. However when in 1611 the Bishop of Mazzara proposed to the Jesuits of Malta to hold a mission on the nearby island of Pantelleria, this was done on the assumption that the natives spoke "arabico" like the Maltese. ${ }^{15}$ The Jesuit province of Sicily

13 'Et verra' molto a proposito anchora farsi un collegio in Malta (come il vescovo de quella isola molo il desidera, et per questo effetto pensiamo si mandera' ivi il P. Bobadilla questo settembre), dove la propria lingua e' l'arabica...", Monumenta Ignatiana. Epistolae ex autographis, VII, letter 4697: 4 August, 1554, p. 379. See amongst others, Borg, Vincent, "Gerolamo Manduca: his life and works", Melita Historica, 7/3, (1978), pp. 237-7. A detailed account of the plans to set up a Jesuit College in Malta based on correspondence can be found in Borg, Vincent, Melita Sacra. The Maltese Diocese during the Sixteenth Century, vol. II (Malta; Gutenburg Press Ltd., 2009), pp. 57-62.

${ }_{14}$ Monumenta Ignatiana. Epistolae ex autographis, VIII (Madrid: G. Lopez del Horno, 1909), letter 5012, p.144: 5 December, 1554.

15 “...ma perche gli habitanti parlano arabico come li maltesi, il Padre Cosimano sara' ottimo per questa impresa... ", Archivum Romanum Societatis Iesu Sicula [hereafter ARSI Sic.], VI, f. 279: 20 August, 1611. 
complied with the wishes of the prelate and sent Maltese missionaries to Pantelleria. By the early seventeenth century the Jesuit Curia in Rome was concentrating its efforts on the newly established Maronite College, formally set up in 1584 . This may suggest that the Jesuits were by then seriously considering the Maronites of Lebanon as potential missionaries to the Levant rather than the Maltese. However, intermittent contact with the Maltese authorities over the possibility of opening a College continued. Thirty eight years were to elapse before a Jesuit College finally opened its doors in Malta in March 1592. The Father General Claudio Aquaviva (1581-1615) directed the provincial of Sicily to send some fathers to Malta only after much insistence from the Pope himself. ${ }^{16}$ The deed for the erection of the College was drawn up on 12 November 1592, and confirmed in July 1593 by Pope Clement VIII. ${ }^{17}$ The arrival of the Jesuits was hailed as a political victory by the Order of St John. The Knights had managed to bring the Jesuits to Malta partly through the great respect and esteem the Society of Jesus entertained for the Order's crusading spirit. It blended well with the Jesuit aspiration of missionary activities in the Levant.

Successive Jesuit Superior Generals seemed to hold the Knights of the Order in high-esteem and it was not rare to describe the Grand Master of Malta as "supreme commander of the most glorious military order, which defends with blood and life the honour of Christ, and that of the Church" ${ }^{18}$ This assertion by the Father General Giovanni Paolo Oliva (1661-81), in a letter addressed to the Inquisitor of Malta, Giacomo Cantelmo (1678-83) in 1680, may explain why successive Generals of the Society of Jesus urged Father Provincials of Sicily to take special care of the College of Malta and to ensure that it was properly staffed. Similar preoccupations emerge in letters

${ }^{16}$ ARSI Sic., V, f. 59: 14 March, 1592.

17 Batllori, M., "Del Col.legi dels Jesuïtes a la Universitat de Malta", Journal of the Faculty of Arts, 6/4 (1977), 189-200, p.189; Fiorini, Stanley, "The Collegium Melitense and the Universitas Studiorum to 1798”, in Yesterday's Schools. Readings in Maltese Educational History, ed. Sultana, Ronald G. (Malta: PEG Ltd., 2001), p. 34.

18 The image of the Order of St John as a defender of Christianity was still very strong many decades later. The Superior General had just learnt of the election of the new Grand Master Gregorio Carafa and felt duty-bound to write to the Inquisitor as the representative of the Holy See in Malta. Oliva explained how he wished to pay his respects personally to the Grand Master but could not do so partly because of the need to administer the Society of Jesus and partly due to his old age. But he still wished to congratulate the "Comandante supremo del più glorioso ordine militare, che difenda col sangue, e con la vita l'honor di Christo, e della Chiesa”, ARSI Sic., XXIII ii, f. 294-v: 16 June, 1680. 
addressed to Visiting Fathers who were sent to check on the everyday running of the College.

The Visiting Fathers were often urged to accept Maltese novices even when the Rector in Malta and the Provincial in Sicily were not particularly impressed by the intellectual abilities of a particular candidate. The reason for this insistence was based on the prevailing belief that the Maltese had a natural aptitude to learn Arabic. In 1625 Father General Mutio Vitelleschi (1615-45) went so far as to advise the Provincial of Sicily to be more lenient when receiving Maltese youths within the ranks of the Society, once they had acquired the necessary qualifications. Vitelleschi required one specific requisite from the Maltese candidates - they had to learn to read and write Arabic before joining the Company as they could be channelled to foster pastoral work among Arabic speakers. ${ }^{19}$

Father Vitelleschi's insistence on encouraging Maltese novices to join the Company ${ }^{20}$ is clearly evinced in the case of a young Maltese man by the name of Tonna. In 1630 Tonna applied to join the Company but the Rector of Malta was hesitant to accept him since the young man was weak, "fiacco", in grammar. Yet the General urged the rector to accept Tonna on the assumption that although the young man was weak in grammar, he knew Arabic and that made him an acceptable enough candidate. ${ }^{21}$

Despite the ups and downs of the school of Arabic, Jesuit policy to use Malta as a base for Christian missions in the Levant continued to hold in the eighteenth century. Nevertheless, there seems to have been a change of focus by that time since later Generals were of the opinion that Maltese Jesuits would do better to stay in Malta and preach to the locals in their native language and potentially convert Muslim slaves living on the island. ${ }^{22}$

19 On 18 December 1625 the Father General urged the Provincial of Sicily "Similmente raccomando caldamente a V.R. che sia anco facile ricevere i Maltesi di lingua arabica atti per la Compagnia, e raccomando al P. Rettore di Malta, che procuri che questi giovani che dimandano la Compagnia imparino a scrivere, e leggere la lingua arabica”, ARSI Sic., IX, f. 92v. See also Borg, "Girolamo Manduca", p. 251, n.40.

20 "il Signore accresca loro lo spirito della Compagnia per poter servirlo con molto frutto", ARSI Sic., VIII i, f. 71v: 30 July, 1620.

21 "si bene il giovane nella grammatica e' fiacco, ha nondimeno la lingua arabica che mi fa inclino ad accettarlo, tanto piu' che si piglia in prova”, ARSI Sic., X i, f. 53v: 4 April, 1630 .

${ }^{22}$ In 1719 the rector of Malta, Father Francesco Castiglia, suggested that Rome should transfer Brother Pietro Medici from Frascati to Malta since this polyglot Jesuit had knowledge of Turkish which would be most beneficial in Malta where he would be able to "care for slaves", ARSI Sic., XXXXVIII, f. 106: 22 April, 1719. 
There had been several attempts to introduce the teaching of Arabic in other parts of Italy outside Rome. In December 1610 the General, Father Claudio Acquaviva ordered the Provincial of Sicily to comply with a recently published Bull of Pope Paul V insisting on the teaching of Arabic in all Sicilian seminaries. Acquaviva, singled out the Maronite-born Jesuit Father Pietro Metoscita and ordered his immediate transfer from Messina to the recently established academy of Arabic in Rome. The General augured that the Academy would become the focal point of Arabic teaching for missionary purposes ("farla rendere con fervore"). ${ }^{23}$

Acquaviva's wish to comply with the Pope's order was great and he complained to the Father Provincial about Metoscita's seemingly unnecessary delay in reaching Rome. ${ }^{24}$ Nonetheless, Metoscita complied with the General's wishes. In autumn 1614 the Jesuit rector in Malta was anxiously awaiting the arrival of Metoscita, and his companion Father Marietti, on their way to the Levant. ${ }^{25}$ They must have reached Malta by then as in September 1615 the two fathers were preaching at Aleppo. ${ }^{26}$ By the end of 1616 they had reached Babylon (in modern Iraq) ${ }^{27}$ from where they returned to Malta soon afterwards. Significantly, Father Marietti left some liturgical vestments as charity for the missions in the Levant before the two Jesuits returned to Rome. ${ }^{28}$

${ }^{23}$ Father Pietro Metoscita (al-Matushi), a Maronite from Cyprus, was one of the first pupils of the Maronite College in Rome and joined the Society of Jesus in 1597. He composed an elementary grammar in Latin to assist the teaching of Arabic entitled Institutiones linguae Arabicae ex diversis Arabum monumentis collectae, \& ad quammaximam fieri potuit brevitatem, atque ordinem revocatae (Rome: Stefano Paolini, 1624). The book was dedicated by the publisher, Stefano Paolini, to Cardinal Francesco Barberini, who had commissioned its publication. In 1610 Father Metoscita formed part of a group of experts in Oriental Studies at the time congregated at Messina, ARSI Sic., VI, f. 257: 11 December, 1610.

${ }^{24}$ On that occasion the General wrote to the Father Provincial that Father Metoscita was still waiting for his order to be transferred to Rome, ARSI Sic., VI, f. 263v: 5 February 1611.

25 Father Metoscita, and his companion Father Marietti, were to reach Malta from where they could leave on a mission to the Levant. However due to rough weather conditions Father Metoscita was unable to travel to Malta in October 1614, ARSI Sic., VII, f. 18: 12 October, 1614. But by late November he informed Father Nicolò Cusmano that Fathers Metoscita and Marietti should be on their way to Malta, ARSI Sic., VII, f. 25v: 22 November, 1614.

26 ARSI Sic., VII, f. 68: 12 September, 1615.

27 'Li Padri di Babilonia sono gia' arrivati per gratia del Signore et haverei havuto molto piu' alleggrezza se non vi fusse stata qualche disunione fra di loro", ARSI Sic., VII, f. 166v: 19 November 1616.

${ }^{28}$ In March 1617 the General, Father Vitelleschi, wrote to the Rector in order to express his disappointment that a liturgical vestment and a chalice transferred to Malta from Rome by Father Giovanni Antonio Marietti and meant to be bestowed as charity to a priest, brother of Father Metoscita, had been left in Malta. The General stated that these were necessary for the celebration of mass in the Levant ...in quei paesi... and urged the rector to send them to the priest without delay, ARSI Sic., VII, f. 205: 4 March, 1617. 
The documentary evidence goes on to confirm the importance played by the Malta Jesuit College. The Jesuit reports dated to the later 1620s further confirm the important role played by the college as a potential centre for exchange between Rome and the Levantine Christians. In one such letter, addressed to the Provincial at Messina, Father General Vitelleschi wrote about his plans for the Maltese Jesuit Father Onorato Pace. ${ }^{29}$ Father Pace was to study Chaldean, as well as teach Arabic, in the Maronite College in Rome, besides serving as confessor to the Maronites. ${ }^{30}$ Father Pace seems to have found it hard to cope with his studies, teaching and pastoral duties. ${ }^{31}$ Whatever the case he successfully terminated his studies in Rome. By February 1629, Pace was delivering Arabic lessons in Malta and preaching in Maltese. ${ }^{32}$ Father Pace's success was of great satisfaction to the General who believed that by preaching to the Maltese in their native tongue Father Pace could effect a true conversion among the faithful. ${ }^{33}$

Father Pace must have left a very good impression in Rome. In June 1628, the Rector of the Malta College was asked to choose a Maltese candidate to serve as Prefetto di Camera at the Maronite College of Rome. According to the letter, the eligible candidate was to be ideally a young Maltese Jesuit aged 22 or 23, who knew the language and customs of the Maronites. ${ }^{34}$ It seems though that the Rector of Malta was slow to reply. His letter dated 18 July arrived when the Maronite College had already chosen someone for the post. In the end, the criteria for the appointment changed and the College opted for

29 Sicily was temporarily divided into two provinces one headed by Palermo and the other by Messina in 1626. At first the College of Malta was not included with one of the two provinces but was eventually integrated into the province of Messina, ARSI Sic., CLXXXVII, f. 292-v.

${ }^{30}$ ARSI Sic., IX i, f. 92v: December 1625. Links between the Maronite community and the Holy See began to evolve with the arrival of the Franciscans in the Levant around 1439. The Jesuits, who founded the Maronite College in Rome in 1584, took over from the Franciscans and remained at its helm until the suppression of the Company in 1773. The College, under Jesuit direction, trained many priests and prelates conscious of the specific problems of Christianity in the Levant. Herzstein, Rafael, "The foundation of the Saint-Joseph University of Beirut: the teaching of the Maronites by the Second Jesuit Mission in the Levant', Middle Eastern Studies, 43/5 (2007), p. 749.

31 It seems there was some complaints about his teaching or confessing activities. In a letter to the Rector in July 1626 the General explained that besides studying, Father Pace was expected to do some service like everyone else, "Il P. Onorato Pace e' stato chiamato qua per finire li suoi studii et per residente fa qualche cosa come fanno tutti gl'altri”, ARSI Sic., IX i, f. 270v: 23 July, 1626.

32 ARSI Sic., IX i, f. 445: 15 March, 1629.

33 ARSI Sic., IX i, f. 457v: 26 April, 1629.

34 "si desidera haverlo da Malta, che sappia la lingua, ed i costumi.", ARSI Sic., IX I, f. 393v: 8 June, 1628. 
an older candidate. ${ }^{35}$ Yet the fact remains that initially a Maltese Jesuit was considered to be an ideal candidate for the task.

Perhaps the close connection between the Maltese Jesuits and the Maronite College in Rome is best evinced in the travelogue of the Maltese Jesuit Domenico Magri, Breve racconto del viaggio al monte Libano di Domenico Magri maltese, which was published in Rome in 1655. Began in December 1623, the trip to the Levant, was mainly intended to recruit students for the Maronite College and the 19 year-old Maltese novice, Domenico Magri, was chosen to accompany Cardinal Orsini and others. Evidently, the selection of Magri was no coincidence. His knowledge of Maltese made him an obvious candidate for the trip. ${ }^{36}$

There are instances which confirm that in the early seventeenth century Jesuits seem to have preferred men of Maltese extract in their dealings with the Arab speaking world. On one occasion when Father Jacomo Marcellaia, the Jesuit missionary in Cairo, needed a dragoman, he engaged the Maltese surgeon Dr Giacomo Chidoni. Chidoni was willing to accompany the Jesuit Fathers all the way down to Ethiopia, one must add, to their great relief. $^{37}$

The general belief in the ability of the Maltese to communicate with Arabs was so highly entrenched that many Maltese Jesuits came to believe that they were in a unique position to carry out missions in the Levant and to convert non-Catholic Christians from as far afield as Ethiopia. For example in 1621 the Maltese Jesuit Father Giacomo Cassia asked to be sent to Ethiopia on the basis of full backing from the Bishop Malta. ${ }^{38}$ One cannot be sure that Father Cassia had ever studied Amharic. He may have simply had some knowledge of

35 ARSI Sic., IX i, f. 407: 17 August, 1628.

36 Magri, Domenico, Breve racconto del viaggio al monte Libano di Domenico Magri maltese. Nell'età sua d'anni 19, was dedicated to Cardinal Carlo Barberini. A second edition was published in Viterbo in 1664. Domenico Magri was, at the time of publication, professor of theology and linguistics in Rome. He recalled the trip to the Levant which was led by Cardinal Orsini. They left Rome in December 1623 and travelled through Gaeta, Naples, Messina, Malta, Crete, Alexandria, and Aleppo until they finally reached Lebanon in June 1624. The mission returned to Rome in November 1624. Magri's detailed account of the mission provides much information on the towns and places he had visited including descriptions of the people he met, their lifestyle, and details on the hierarchical structures among Levantine communities.

37 According to Father Marcellaia, he was willing to accompany possibly hoping to make his fortune there, since he was very fluent in Turkish, Moorish and Greek, ARSI Sic., CLXXXIV i, ff. 14, 18: 3 April, 1628.

${ }^{38}$ Father General Vitelleschi explained to the Bishop that "the mission is destined to few although many dream of going" (la missione e' destinata a pochi e' da molti desiderata), ARSI Sic., VIII i, f. 208: 16 September, 1621. 
Arabic. It may also be that he had both languages. He may have studied neither of the two languages. In that case, Cassia would have simply been expressing a genuine wish to join the throng of many other members of the Society of Jesus, and other religious orders, in their desire to join the missions in the Indies.

\section{The School of Arabic: Malta, Rome and the Levant}

Despite their interest in the Levant and their work in Malta the Jesuits were never formally connected to the Congregation of Propaganda Fide which in the end decided to set up a formal school of Arabic in Malta. This is not to say that Jesuits had little or no influence on the activities or decisions taken at the Congregation of Propaganda Fide. Several scholars suggest that a chapter entitled 'De erigenda congregatione pro fide propaganda', published by the Spanish Carmelite Thomas de Jesús, in Antwerp (1613) was inspired by Jean de Venderville's redraft carried out by the Jesuit Antonio Possevino (15331611). ${ }^{39}$ Another issue in which Jesuits seem to have been influential was the teaching of Arabic to Maltese candidates. It was thought feasible to send the most promising to preach in Ottoman lands - in the Levant and especially in North Africa - a theme that seems to have been close to the heart of first the Jesuits, and later of several other religious orders. ${ }^{40}$ It could even have been inspired by the unsuccessful four year mission of Leonardo Abel (1583-87) to the Levant.

Whatever the case, the Congregation of Propaganda Fide was showing considerable interest in making Malta a base for the teaching of Arabic for missionary purposes. In March 1624 less than two years after its foundation, the Congregation of Propaganda Fide informed the Inquisitor of Malta, Carlo Bovio, Bishop of Bagnarea, of its wish to set up a school of Arabic. Inquisitor Bovio could appreciate that Malta was potentially an ideal base to teach Arabic to regular and secular clergy. Bovio agreed that it was possible to send Maltese missionaries to Muslim lands ("in partibus infidelium”) to preach the Gospel. The arguments put forward by the Congregation and expressed by the Inquisitor were not much different from those put forward by the Jesuits.

\footnotetext{
39 Donnelly, John Patrick, “Antonio Possevino's plan for world evangelization”, The Catholic Historical Review, 74/2 (1988), 179-98, p. 181.

${ }^{40}$ There is no direct indication that Arabic was taught at the Jesuit College in Valletta although Paul Mallia suggests that it was taught there, Mallia, Paul, Il-Gizwiti [The Jesuits] (Malta: s.n., 1970), p. 49.
} 
The most essential aspect on which Bovio concurred with the Congregation was that the mother tongue of Malta was "a corrupt form of Arabic" that was understood in North Africa. Nor, he claimed, could anyone in Malta read, or write, Arabic with the result that hardly anyone was able to teach its grammar. Worse still, most Maltese clergy were reluctant to study the language. Bovio was convinced that the best way forward would be to invite a Maronite from Lebanon, or maybe someone based in Rome, who could teach Arabic in Malta. Finally, he had personally approached several Jesuit, Capuchin, and Dominican friars who normally preached in Maltese. Bosio was convinced of the utility of these friar preachers for missionary activities in North Africa and the Levant. He concluded that their Maltese speech may have sounded like a corrupt form of Arabic but the native populations could understand them. ${ }^{41}$

The school of Arabic did not materialize during Bovio's time as inquisitor. Fra Francesco di Malta, a Franciscan Friar, whom Antonio Cremona claimed to be called flieles had already been selected by Propaganda Fide to teach Arabic in $1628 .^{42}$ By early 1632, Fra Francesco was teaching four students, sent expressly from the province of Noto in Sicily, to read Arabic. ${ }^{43}$ We learn that Fra Francesco served as Turcoman or official interpreter of Arabic for the Order of St John. In the early twentieth century, a Franciscan writer went so far as to point out that by 1632 the Franciscans had established a centre for the teaching of Arabic at their convent in Rabat, where Fra Francesco was superior. He further argued that in Rabat Arabic was still being taught in 1679 . The statement, repeated by Antonio Cremona, was more recently disclaimed by Dionisius Agius. ${ }^{44}$ Whatever the case, the sudden death of Fra Francesco, early in 1632, must have destabilised the teaching of Arabic in Malta for some years. $^{45}$

${ }^{41}$ Archivum Sacra Congregatio de Propaganda Fide [hereafter ASPF], Scritture Originali dei Congressi Generali [hereafter SOCG], CCCLVIII (1625), f. 54: 25 March, 1624.

${ }^{42}$ Cathedral Archives Mdina [hereafter CAM], Archives of the Inquisition of Malta Correspondence [hereafter AIM Corr.], XXXVI, f. 1: 13 February, 1628; cf. Cremona, "L'Antica

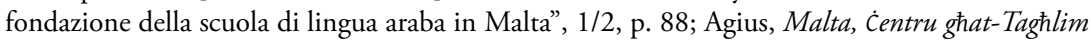
ta' l-Gharbi, p. 46.

43 ASPF, SOCG, VII (1632), f. 244: 15 September, 1632; f. 245: 25 November, 1631. Fra Francesco asked the Congregation to send him four Psalters, and possibly at a later stage, the gospels and an Arabic language grammar, ASPF, SOCG, VII, ff. 245; 248v.

${ }^{4}$ Scerri, Giorgio, Malta e i Luoghi Santi della Palestina (Malta: Lux Press, 1933), p. 56. This was repeated by Cremona, "L’Antica fondazione della scuola di lingua araba in Malta", 1/2, p. 88; Agius, Malta, Centru ghat-Taghlim ta' l-Gharbi, pp. 10-11, n. 17.

45 Agius, Malta, Centru ghat-Taghlim ta' l-Gharbi, p. 2. 
Nonetheless, other prelates of the Catholic Church in Malta including the Jesuit-trained Inquisitor Fabio Chigi (later Pope Alexander VII) apparently shared the belief in the potential of the Maltese as missionaries among Arabic speakers. In May 1637 Chigi wrote to Cardinal Barberini that

Only in the Island and diocese of Malta, among all the Catholic Christians is the Arabic language preserved up to this day... this language is of great benefit to Christianity, for the missions in the Levant, as well as to publish books in Arabic,... nor is there a better place than this Island to plan events since the locals can understand most of that language $[$ Arabic $] \ldots{ }^{46}$

Chigi's letter appears to have convinced the Sacred Congregation of Propaganda Fide to agree that the time was finally ripe to establish a school of Arabic in Malta. By 30 September 1637 the Sacred Congregation of Propaganda Fide informed Chigi that Don Francesco Azzupardo, then still in Rome, had been chosen as lecturer of Arabic. The benefice of Santa Cecilia, popularly known as Ta' l-Isqof, in Gozo was chosen as the source of revenue for Azzupardo and other future holders of the post of Arabic. ${ }^{47}$ However, as the holder of the benefice, the septuagenarian Canon Giovanni Habela, was still alive, Don Azzopardo was bound to wait and the activities of the school of Arabic were kept on hold. ${ }^{48}$ By January 1638, Inquisitor Fabio Chigi expressed hopes of the imminent arrival of Don Azzopardo in Malta. ${ }^{49}$ But the choice of Don Azzupardo did not go down well with the Franciscans who claimed that they should have priority over the secular priesthood in such matters as the teaching of Arabic on the grounds that their interest in the Holy Lands dated back to the times of their founder, Francis of Assisi. The argument that ensued confirms beyond doubt that the teaching of Arabic in Malta was intrinsically linked to missionary activities in the Levant.

46 "Solo nell'Isola e diocesi di Malta, fra tutti li Cattolici Christiani si conserva hoggi tuttavia la lingua Araba...essendo di sommo benefitio alla Christianità questa lingua, si per le missioni in oriente, si per la communicatione de' libri Arabici, per il profitto d'Historie, ed' alcune scienze, ne potendosi più meglio cultivare che in dett'Isola, per la facilità de gl'aventi che n'hanno i naturali e l'intender essi gran parte di quell linguaggio", BAV Chigiani [hereafter Chigi], vol. A.I.4, ff. 214v-215. Chigi to Barberini: 15 May, 1637. Cf. Gambin, K., "Fabio Chigi: InquisitorMissionary and Tridentine Reformer", Unpublished MA Dissertation, University of Malta, 1997, pp.199-200.

47 ASPF, SC, I, f. 322.

48 ASPF, SOCG, XXIV, f. 319-v and BAV Chigi, vol. A.I.4, f. 333v. Both documents are dated 2 February, 1638. In the second letter, written by Chigi and addressed to Mons Ingoli, the Inquisitor complained that the stipend for the post of lecturer of Arabic was too small. See also Cremona, "L'antica fondazione della scuola di lingua araba in Malta", 1/2, p. 91; 1/3, p. 143.

49 ASPF, SOCG, XXIV, f. 316: 11 January, 1638. 
The Franciscans tried to solve the problem by proposing the setting up of their own Arabic teaching school, a suggestion duly pushed by Fra Gerardo Milanese, a Franciscan missionary of Ethiopia. ${ }^{50}$ By March Fra Gerardo Milanese was already complaining that the priest Azzupardo was simply teaching some rudimentary Arabic from his home to young boys (figlioli) who could not be of service to the Holy Congregation of Propaganda Fide. Fra Milanese therefore suggested the use of the Franciscan friary that could easily accommodate a minimum of ten students. The friar evidently had the mission he served at heart and wished to be able to make good use of the services of his Maltese brothers. He complained that none of them could read or write Arabic although their common parlance was Arabic (that is Maltese). However, they communicated freely with the Arabs of the Levant and the West and from his studies in Rome, he judged the language to be in substance close to the Maltese language. ${ }^{51}$

The Franciscans had the chance to manoeuvre largely because, although Don Azzupardo was chosen to teach Arabic, the benefice attached to it had not yet become vacant and no Arabic lessons were being delivered to potential missionaries. Indeed the ailing beneficiary of the benefice, Don Habela, was still living in $1642 .{ }^{52}$ The arrival of the Maronite priest, Giovanni Auriano, sent expressly to Malta from Rome to teach Italian to young boys by the Patriarch of Antioch, but also a native Arabic speaker, induced some discussion in favour of appointing him as teacher of Arabic instead of Azzupardo.

Auriano received very strong support from the Greek Uniate archimandrite Papas Andrea Paleologos of Constantinople. Paleologos argued convincingly that Don Giovanni Auriano deserved the benefice of the deceased Don Habela and ideally should be offered the post of Arabic because he was a native Arabic speaker who could teach the language properly. Archimandrite Paleologo believed in the need to teach Arabic in Mata due to its geographic proximity to Libya, meaning the Maghreb. ${ }^{53}$ Don Auriano explained that he would

\footnotetext{
${ }^{50}$ Fra Gerardo Milanese, a Franciscan missionary of Ethiopia, went so far as to suggest his fellow Franciscan brother Fra Archangelo di Malta, then Commissioner of the Holy Lands in Rome, as ideally suited to set up a training centre for missioners to the Holy Lands in Malta. Fra Gerardo believed that Franciscan missionaries passing through Malta would prefer to deal with a fellow Franciscan than a secular priest, ASPF, SOCG, XXIV, f. 337: 26 January, 1638.

51 ASPF, SOCG, XXIV, f. 339: 12 March, 1638.

52 In mid August 1642, Inquisitor Gori Panellini informed the Congregation of Propaganda Fide that the benefice should soon become available as the ailing Don Giovanni Habela was expected to die, ASPF, SOCG, CLXVII (1642), f. 350: 18 August, 1642.

53 ASPF, SOCG, CLXVII, f. 408: 5 December, 1642. Letter of Don Auriano to Secretary of Propaganda Fide Mgr. Francesco Ingoli.
} 
gladly oblige if given the chance to teach Arabic $^{54}$ and was even prepared to share the income from the benefice associated to the teaching post with Don Azzupardo. Don Auriano pointed out amongst other things that "I am of the same language [Arabic] and as a consequence I have better cognizance of the vocabulary and the grammar than the Maltese, as they themselves confess, because they speak an Italianate Arabic which is very different from ours". 55

In the end, an agreement was reached by which Don Auriano would hold lessons in Vittoriosa and Don Francesco at Valletta. However, this did not work out. There were hardly ten students of Arabic in all and none hailed from Vittoriosa. As a result, it was useless to hold Arabic lessons there. It was said that the people of that area were more interested in looking for a job and preferred to study Latin as Arabic was of little use to them. On the other hand, the citizens of Valletta were generally comfortably well-off and could afford to dedicate some of their time to the love of knowledge. In the end, it was feasible to teach Arabic only in Valletta and the obvious candidate for the job was undoubtedly Don Auriano. Auriano was not only a native speaker but had even spent some time teaching Arabic at the Maronite College in Rome. The fact that Don Azzupardo agreed to share the meagre revenue from the benefice attached to the teaching of Arabic confirms that his knowledge of the language was rather limited, restricted as it was to reading. ${ }^{56}$ In the end it seems that Paleologo's insistence was convincing enough and the Maronite priest was offered the post of lecturer of Arabic with a yearly stipend of 120 scudi, from the benefice of Ta' l-Isqof in Gozo, attached to it. He kept the post with the blessing of the Patriarch of Antioch to the satisfaction of the Maltese authorities for a couple of years as confirmed in his letter of resignation two years later when he was ordered to return to the Levant by the Patriarch. ${ }^{57}$ The departure of Don Auriano was probably a great loss to the teaching of Arabic

\footnotetext{
${ }^{54}$ Letter by Don Auriano to the Cardinal Prefect of Propaganda Fide, ASPF, SOCG, CLXVII, f. 417: 28 July 1642. On the orders of Propaganda Fide Don Auriano was instructed to leave for Lebanon in April 1641, ASPF, SOCG, CLXVII, f. 344: 10 March, 1642. But he was ordered back to Malta to try to raise a sum of money and liberate himself from a price demanded by the Turks ("Mons. Patriarca... l'ha rimandato in Malta, per procurar elemosina, per poter liberarsi d'una grossa taglia, messali dalli Turchi)". Auriano reached Malta before 28 July, ASPF, SOCG, CLXVII, f. 348: 9 July, 1642; f. 349: 28 July, 1642.

55 ASPF, SOCG, CLXVII, f. 408: 5 December, 1642. Letter of Don Auriano to Secretary of Propaganda Fide Mgr. Francesco Ingoli.

56 Letter of Archimandrite Papas Andrea Paleologo to Mgr Ingoli Secretary of Propaganda Fide, ASPF, SOCG, XXXIX (1643), ff. 19v-20: 30 January, 1643.

57 ASPF, SOCG, CXXIII (1644), f. 320: 3 October, 1644.
} 
in Malta as the available documentation seems to suggest. The exercise was not sustainable mainly because the benefices of Malta were meant solely for the Maltese, or at least for someone who was directly involved in the service of the diocese. ${ }^{58}$

A Maltese secular priest, Don Salvatore Fenech, filled the post of Arabic soon after he finished a six-year period of studies in Rome. He succeeded Don Auriano. Fenech wrote a petition in which he claimed that the income of 120 scudi per year from the benefice at Ta' l-Isqof was insufficient for his needs and asked the Congregation to consider granting him some other benefice or a post of canon to be able to carry out his work with dignity. ${ }^{59} \mathrm{He}$ claimed that he needed to keep an attendant who bought food and other items for everyday needs, that he spent over 25 scudi per year for clothes, and was further obliged to keep a horse in order to be able to travel back and forth from his home, all of which incurred expenses in the range of 200 scudi per year. As he hailed from a background with very limited means and was rather poor, Fenech complained that his real expenses were somewhat higher as he needed to sustain both his elderly parents and seven minor brothers and sisters. ${ }^{60}$

Don Auriano appears to have set up a solid base for the teaching of Arabic at the convent of the Discalced Carmelites at Cospicua that could have potentially led to the setting up of a solid centre for the teaching of Arabic in $1644 .^{61}$ Don Salvatore Fenech was teaching Arabic to the great satisfaction of the friars there in 1646. ${ }^{62}$ By early 1647 the Inquisitor Antonio Pignatelli (later Pope Innocent XII), claimed that the Discalced Carmelites had sent no less than 14 friars as missioners in the Levant and provided the impressive list of friars who studied Arabic in Malta and another list of eight friars who were at the

58 ASPF, SOCG, XLIX, f. 209v: 8 July, 1646.

59 ASPF, SOCG, XLIX, f. 209. In another letter he wrote that the revenue from the benefice barely reached 80 scudi per year. He added that he was able to spend seven years in Rome and study there thanks to the constant support of his uncle, Father Baldassare Fenech, an Augustinian friar in Rome.

${ }^{60}$ Amongst other matters, Fenech complained that he gave out six doctrine books in Arabic which he distributed to his students of Arabic free of charge and they did not even bother to thank him, ASPF, SOCG, XLIX, f. 209-v: 8 July, 1646.

${ }^{61}$ The foundation act of the convent of St Theresa at Cospicua was ratified in the Acts of Notary Pietro Buttigieg on 29 August, 1644. See ASPF, SOCG, CCCLIX (1648), ff. 209-210v.; and approved by Grand Master Lascaris on 3 December, 1644, Ibid., ff. 210v-211.

62 See the letter by the French Discalced Carmelite Friar Domenico of the Holy Trinity ("della Santissima Trinita”), lecturer of theology and student of Fenech, ASPF, SOCG, XLIX, f. 206: 30 April, 1646; and letter by Fenech addressed to the Congregation of Propaganda Fide, Ibid., f. 205: 4 May, 1646. 
time studying at the convent. ${ }^{63}$ The Inquisitor provided a summary report on the progress of Don Salvatore Fenech as teacher of Arabic. Pignatelli explained that Fenech received revenue from the benefice amounting to around 100 scudi per year from which were paid 15 scudi to a priest who carried out religious services connected to the benefice and another five scudi to the Society of Jesus. He kept his school in Valletta but he had very few students. At the same time he also taught Arabic to some five or six Franciscan friars at their convent in Valletta as well as the Discalced Carmelites at the convent of St Theresa. ${ }^{64}$ Arabic was still taught there in the late seventeenth and early eighteenth centuries but the Discalced Carmelites were concerned with the multitude of slaves that were liberated by Christian corsairs from the Ottomans and brought to Malta. They therefore felt duty bound to insist that the Congregation of Propaganda Fide provide books and teachers in other languages. As early as 1642, before the formal establishment of the college, the Discalced Carmelites asked for and received books in English from the English College in Rome. ${ }^{65}$ By 1675, the presence in Malta of a multitude of foreigners from northern and eastern Europe induced the friars to ask Rome for teachers of European languages such as English, Polish, German, Armenian, and especially Russian since, they explained, speakers of these languages were not easy to come by in Malta. ${ }^{66}$ They later asked specifically for Catholic doctrine books in Croat, ${ }^{67}$ and eventually for a German language confessor who could help convert Lutheran 'heretics'. ${ }^{68}$ The Discalced Carmelites of the seventeenth century appear to have had the kind of religious fervour that Ignatius Loyola and the early Jesuits shared in the mid-sixteenth century.

Whatever the case the fiery enthusiasm of the Discalced Carmelites did not change the mind of the Congregation. Arabic remained firmly under the jurisdiction of diocesan priests and Don Salvatore Fenech continued to serve as lecturer of Arabic until his death in 1689 when the post was offered to Don Fabrizio Bonici. Bonici was to remain at his post until his death in $1729 .{ }^{69}$ Nonetheless, throughout all these years progress in the teaching of Arabic

63 The list of those sent to the Levant included three Sicilians, two Frenchmen, two Lombards, two Genoese, two Neapolitans, and one Flemish. Those still studying were even more mixed. Two were from Siena, and there was one each from Rome, Naples, Sicily, France, Portugal, and Ireland, ASPF, SOCG CLXXV (1647), f. 12.

${ }^{64}$ ASPF, SOCG, CLXXV, f. 13: 24 April, 1647.

65 ASPF, SOCG, XXXIX, f. 4: 26 November, 1642.

${ }^{66}$ ASPF, Scritture riferite nei Congressi [hereafter SC], I, f. 20: 18 October, 1675.

${ }^{67}$ ASPF, SC, I, f. 26: 2 November, 1691.

68 ASPF, SC, I, f. 31: 24 February, 1713.

69 ASPF, SC, I, ff. 59v-60: 28 July, 1729. 
remained very modest. The appointment of Don Gregorio Carbone in November 1729 seems to have led to some solid improvements. In order to generate interest the Congregation of Propaganda Fide introduced yearly competitions in Arabic proficiency. Arabic language students who came first started to receive money prizes. Their numbers increased and, at one point, Carbone had 13 students, six of whom were ordained priests. Yet the numbers remained small. ${ }^{70}$

Despite all the efforts not much progress in teaching was registered. Standards were so low that by 1756 Inquisitor Salviati suggested the setting up of a fund to teach practical modern transalpine languages. Salviati wished to set up a 'House for Converts' where Christian 'heretics' could learn about the Catholic faith. He tried to solve the problem of funding the 'House' by adding the annual sum of 280 scudi allocated to the teaching of Arabic to the capital funds invested in the grain trade (Massa Frumentaria) - and another annual sum of 2,406 scudi - meant to aid the 'African' missions. Salviati insisted that the days in which the Catholic Church invested in the conversion of Muslims were over. He proposed that rather than teaching Arabic the Congregation should concentrate on the teaching of northern European languages. He specifically identified the need to teach English, Dutch, Swedish, Danish and German. ${ }^{71}$ Salviati argued convincingly that only a very small number of students learned Arabic. Those who attended classes did so not out of enthusiasm but rather as a way to try to obtain the revenue associated with the benefice. As a result none of them had any real knowledge and could not use the language either in conversation with 'infidels' or in the missions. Besides, the numbers of students were minimal so that the group of students of Arabic was very small. At times only one student attended. At other times, there were only two or three students. Very rarely did the number reach four or five students. Worse still, the teaching was insufficient. The students attended a weekly lesson, at the lecturer's home, in the afternoon, and it hardly ever exceeded one hour. Further proof of the futility of the teaching of Arabic in Malta put forward by Salviati was that only very rarely did real Arabs ever reach Malta. Instead, he argued, one encountered a multitude of Berbers, whose language was very similar to Maltese. As a result, it was quite normal to come across regular Maltese clergy communicating with them, instructing them, and possibly converting them to the Catholic faith. Salviati believed that Malta could potentially become a base for the conversion of the multitude

\footnotetext{
70 ASPF, SC, I, ff. 85-86: 12 November 1729.

71 ASPF, SC, I, ff. 106v-115v: 30 October, 1756. Don Gregorio was by then an ailing old man in his sixties, Ibid., f. 114.
} 
of Protestants who frequented the shores of the northern Mediterranean. To prove his point he went so far as to provide the Congregation with a list of converts in the previous decade. ${ }^{72}$ However, despite his strong and most convincing argument, Salviati did not manage to change the mind of the prelates who ran the Holy Congregation. As a result, Propaganda Fide continued to adopt its traditional policy insisting that Malta played a vital role in the teaching of Arabic due to its proximity to North Africa and the Levant. In such circumstances, it insisted, the school served as a vital tool.

In the end, Salviati was proved right. Comments published less than two decades after he wrote to Propaganda Fide by the Swedish traveller Jacob Jonas Bijörnsthal, in German, confirm his view. Bijörnsthal visited Malta in December 1770. In his account published a few years after his visit, Bijörnsthal noticed that the Arabs of the Maghreb conversed with the Maltese with great ease. Both North Africans and Maltese understood each other well. Nevertheless, the Swedish visitor observed that the Maltese grammar was not exactly like Arabic. Furthermore, he noticed that the Maltese wrote their 'Arabic' words in the Latin script and justly explained that they had never written in the Arabic script. ${ }^{73}$ Yet despite all the hard evidence to the contrary, coupled with a lack of interest in Arabic on the part of Maltese students, the Congregation insisted on keeping the school of Arabic open. Little was done to improve the quality of teaching.

There was lack of interest. Worse still, there was lack of initiative on the part of the lecturers themselves. In 1762, a mere six years after Salviati's intervention, Inquisitor Durini reported that despite being expected to hold lectures of Arabic at both Valletta and Mdina - presumably Mdina being singled out as the focal point of the diocese - Don Gregorio Carbone only held Arabic

72 “La lettura della Lingua Araba sembra resa quasi inutile in quest'Isola perche pochi son quelli, che v'intervengono, e questo pare, che lo faccino più per rendersi capaci di ottenere il Beneficio, che resta ammesso alla detta lettura, che per altro fine; mentre non si è veduto sortirne alcun allievo che habbia servito di profitto o nella conversazione degl'Infedeli, o nelle missioni.... Le persone che frequentano la scuola di detta Lingua tal volta consistono in un solo, alcune volte in due, o tre, e di rado arrivano al numero di quattro, o cinque... Di rado capitano qui Arabi veri: Ma all'incontro vi sono molti Barbareschi il di cui linguaggio, siccome è molto affine al Maltese: così si possono facilmente trovar qui religiosi capaci di tal Lingua, e in conseguenza di catechizzare e convertire, come si è fatto fin'ora in simili contingenze", ASPF, SC, I, f. $117 \mathrm{v}$.

${ }^{73}$ Bijörnsthal, Jacob Jonas, Briefe aufReisen durch Frankreich, Italien, die Schweiz, Deutschland, Holland, England und einen Theil der Morgemländer (Rostock and Leipzig: Stralsund - Christian Lorenz Struck, 1777), vol. I, p. 218; cf. Freller, Thomas, The Rise and Fall of Abate Giuseppe Vella (Malta: PIN, 2001), p. 18. 
lessons in Valletta. He also failed to hold the bi-yearly examinations of his students and even failed to award the prize to the best student. Durini explained that one could not expect much better from an ailing priest. Five students attended Arabic lessons at the time. That year, thanks to the intervention of Durini, the cleric Carlo Tonna received the prize of ten Roman scudi. ${ }^{74}$ The Inquisitor's intervention appears to have helped keep the number of students stable for some time. Thus, five students were attending classes in $1768,{ }^{75}$ and again in $1770 .^{76}$

The students of Arabic at the time may probably have included the notorious Giuseppe Vella, whose forgery inspired the Sicilian Leonardo Sciascia (1921-89) to write his famous novel, Il Consiglio d'Egitto (The Council of Egypt) in 1963. Vella was probably received as chaplain (Fra Cappellano) of the Order of Malta in 1762 and may have studied with Carbone in his later years. ${ }^{77}$ Carbone died in 1771 and Propaganda Fide took three years to appoint someone to replace him. This may be seen as a sign that Propaganda Fide was at last losing hope in the validity of the exercise, but by 1774 the Congregation had chosen Don Giuseppe Calleja to fill the post of Arabic with the proviso that he would hold exams and award a prize of ten Roman scudi twice a year to the best student. ${ }^{78}$ Despite his promises, Don Calleja failed to award any prizes and in March 1776 he even returned the sum of 30 scudi to the incumbent Inquisitor and Apostolic Delegate Mgr Lante. Calleja explained that he was returning the money partly because he believed it was paramount for students to learn the language first before he could examine them; and partly because the number of students was too small to undergo assessment effectively. ${ }^{79}$ Don Calleja's action led to changes in the examination methods. From

\footnotetext{
${ }^{74}$ ASPF, SC, I, ff. 135-6: 1 December, 1762.

75 These were a priest, three clerics and a laymen: Don Vincentio Tanti, a priest from Valletta; the Cleric Carlo Tonna aged 21; the cleric Michel'Angelo Tonna aged 19; the Cleric Salvator Locorso aged 21; and Francesco Tortell aged 11 from Valletta, ASPF, SC, I, f. 141-v: 4 July 1768.

${ }^{76}$ In 1770 the students of Arabic under the direction of Don Carbone were four clerics and one laymen, Fra Calcedonio Preti and Fra Stephano Psaila, both Chaplains of Obedience of the Order of St John; the clerics Paschale Gelsomino and Gaetano Peres; and the young Magnifico Francesco Tortell, ASPF, SC, I, f. 152-v: 25 October, 1770.

77 Vella gained great fame throughout Europe for his 'translations' of Arabic sources on the history of Sicily and even claimed to have discovered 17 lost books by the Roman historian Livy. Eventually Vella's work was found to be a forgery and a falsification of history, Freller, The Rise and Fall of Abate Giuseppe Vella, pp. 56-7.

${ }^{78}$ Calleja was appointed to enjoy the benefice of Ta' l-Isqof on 28 April, 1774 and was approved by the Congregation of Propaganda Fide on 12 September of that year, ASPF, SC, I, ff. $170,177$.

${ }^{79}$ ASPF, SC, I, f. 181-v: 25 March, 1776.
} 
then onwards examinations took place in the civil chancery of the Inquisitor's Palace under the watchful eyes of the Inquisitor himself.

At least prize giving was re-introduced. In July 1777, Giorgio Desira of Senglea received the prize. ${ }^{80}$ Two years later in April 1779, Giuseppe Camilleri of Tarxien came first ${ }^{81}$ and Giovanni Schembri examined in front of Inquisitor Zondadari was awarded the prize in the following August. ${ }^{82}$ The choice fell on Schembri again in 1780 when only two students sat for the exam. ${ }^{83}$ Prize giving stopped for a time when Don Giuseppe Calleja fell ill. But when they were recommenced in June 1783, two students received a prize. ${ }^{84}$ The examination and prize awarding ceremony became a mainstay of the Inquisitor's Palace well into the 1790s. In 1794, Fra Giuseppe Grassi, a professed chaplain of the Order of St John, won the prize of Arabic. ${ }^{85}$ Despite the improvement in organization, and the scrutiny from Rome, the teaching of Arabic was in full decline. Even so, as late as 1795 , one Michel'Angelo Borg wrote a petition to Cardinal Antonelli, the Prefect of the Congregation of Propaganda Fide, to consider admitting his 13 year-old son, to the College of Propaganda Fide (Urban College) on a scholarship on the basis of

privileges normally conceded to the peoples of the Levant that are likewise enjoyed by the Maltese. The boy has a vocation to become a priest, and lives in Malta. He will be continually occupied with missionary activities, not only vis-à-vis the 'infidels', who reside in Malta in large numbers... but even to the Levantine Catholics, who continually pass from the Levant to the West, or vice versa [through Malta]... ${ }^{86}$

Borg's choice of words took some time to sink in but in the end it worked in his favour. His son was granted a scholarship to study for the priesthood in Rome. ${ }^{87}$ However, the future of the school of Arabic was by then rather uncertain. In 1793 Grand Master De Rohan had already proposed, to the newly arrived Inquisitor Mgr Giulio Carpegna (1793-98), that the teaching of

${ }^{80}$ ASPF, SC, I, f. 198: 17 July, 1777.

81 Three students sat for the exam in 1779. These were Giuseppe Camilleri of Tarxien, (Joanne) Giovanni Schembri of Mqabba, and Giorgio Desira of Senglea, ASPF, SC, I, ff. 227: 21 April, 1779.

${ }^{82}$ ASPF, SC, I, f. 233: 14 August, 1779.

83 The students were Giuseppe Tanti and Giuseppe Schembri, ASPF, SC, I, f. 246: 8 July, 1780 .

${ }^{84}$ The February prize was awarded to Giovanni Schembri and the May prize to Giuseppe Borg, ASPF, SC, I, ff. 262-263: 7 June, 1763.

${ }^{85}$ ASPF, SC, I, f. 275: 15 January, 1794.

${ }^{86}$ ASPF, SC, I, f. 283: 21 July 1794.

${ }^{87}$ ASPF, SC, I, f. 284. 
Arabic should be held at the University and that it should be financed from the benefice of Ta' l-Isqof. It appears that by then the Congregation of Propaganda Fide had finally realized that the days of the school of Arabic in Malta were truly numbered. Times had changed and so had educational structures. The expulsion of the Jesuits from Malta in 1768, led to the setting up of the University of Malta in the following year.

Propaganda Fide kept procrastinating for more than two decades. Then in September 1795, at the instance of Grand Master De Rohan (1776-97) a re-script was published stipulating that whoever enjoyed the revenue of the benefice of Ta' l-Isqof was obliged to teach Arabic at the University of Malta. It stipulated that instead of teaching Arabic the beneficiary should instead catechise the Muslims (Turchi) who wished to embrace the Catholic faith. The income from the benefice should instead be granted to someone who could serve as an English speaking catechist whose job it would be to teach the Catholic faith to those English speakers who wished to abjure their heresy and embrace the Catholic faith. Furthermore, the sum that had previously served to award prizes for the teaching of Arabic became an honorarium to the English catechist.

Inquisitor Carpegna was ready to collaborate with the Grand Master on the proposed changes and took the task of choosing a teacher who could teach English. However, Carpegna needed the blessing of the Congregation in order to be able to proceed. He stressed that the Congregation could not continue to ignore the ever rising number of Englishmen visiting Malta who expressed their wish to join the Catholic faith. ${ }^{88}$ Carpegna and the ruling Grand Master could not make the necessary changes and had to wait a few more years until the benefice fell vacant. In 1795, the University of Malta took over the lectureship in Arabic. Don Giuseppe Calleja, the lecturer of Arabic, died on 19 May $1798 .{ }^{89}$ Inquisitor Carpegna left Malta within a week, on 26 May, a mere two weeks before the French Republicans occupied the island. ${ }^{90}$ In the meantime, the post of lecturer of Arabic, and the benefice associated with it, was vacant. The holder of the benefice was exempted from teaching and the ten Roman scudi normally destined as prizes for the best students of Arabic were paid to the English language catechist. ${ }^{91}$ The propositions

\footnotetext{
${ }^{88}$ ASPF, SC, I, ff. 297-99: 28 January, 1796.

${ }^{89}$ ASPF, SC, I, f. 322. Cremona adds that he died at his residence in Tarxien. "L'antica fondazione della scuola di lingua araba in Malta", 1/2, pp. 94-5; 1/3, pp. 142-3.

${ }_{90}$ The French took Malta on 12 June, 1798. See Bonnici, A., Storja tà l-Inkizizzjoni tà Malta [History of the Inquisition of Malta], vol. III (Malta: Religjon u Hajja, 1994), p. 535.

${ }^{91}$ ASPF, SC, I, f. 322v.
} 
put forward by Mgr Salviati some 40 years earlier had finally been heeded. But the changes came too late. So late, in fact, that they did not have the desired effect.

\section{The nineteenth and twentieth centuries}

At any rate, Arabic remained on the list of subjects officially taught at the University of Malta and there were applicants who claimed they could teach it. A couple of applications for the benefice attached to it, claiming a proficiency in the language, were put forward immediately after the turmoil that followed the French occupation had ceased. Both applicants were chaplains of the new defunct Order of St John. The first was Fra Giuseppe Simone Borg - a lawyer, holder of the chair of civil law at the university, and a Maltese chaplain of the Order of St John - petitioned to obtain the benefice on the assumption that he attended the school of Arabic and had received the price attached to it several times. ${ }^{92}$ Borg managed to acquire the post but must have felt uneasy teaching Arabic and asked instead to be allowed to teach Christian doctrine. As a result, on 27 July 1801 the Congregation of Propaganda Fide decided to postpone the remuneration attached to the benefice until some stability was reached. ${ }^{93}$ By 1802 , immediately after the Great Powers agreed to return Malta to the Order of St John in the Treaty of Amiens, another Maltese Chaplain of the Order of St John, Giuseppe Grassi, claimed that there was no need for further deferment. Grassi was so confident of his knowledge of Arabic that he offered to be examined in Rome on his proficiency in the language. He claimed that the University was still functioning in Malta and whatever the future held for Malta there would always be a need of spiritual assistance to people from the Levant, whether businessmen, or slaves, who resided in Malta. For this reason, Grassi claimed that it would always be necessary to have priests knowledgeable in Arabic. He argued that the benefice would thus prove a useful tool to this end and the large number of attestations presented to Mgr Secretary of the Congregation could prove his point. Grassi boasted that in Malta no one else was able to read Arabic. He added that the incumbent Fra Simone Borg could not create any obstacles partly because Borg was unable to teach Arabic, as he had himself confessed, and partly because he occupied the chair of civil

\footnotetext{
${ }_{92}$ Fra Borg claimed to have been awarded the prize twice in the presence of Inquisitor Zondadari (1777-85) and once during the Inquisitorship of Mgr Gallarati Scotti (1785-93), ASPF, SC, I, f. 323.

${ }_{93}$ ASPF, SC, I, f. 328.
} 
law at the same university. ${ }^{94}$ In the end, neither Borg nor Grassi made any progress in their claims. On his part, Cardinal Gerdil, the Prefect of the Congregation of Propaganda Fide, instructed Mgr Labini, the Bishop of Malta, to keep the benefice vacant. Labini was to nominate an executor and transfer the revenue, amounting to 140 Roman scudi, to a new fund meant to assist the missionaries of Tripoli. ${ }^{95}$ As a result in 1805 the British Civil Commissioner, Sir Alexander Ball, chose the Franciscan friar, Father Anastasio, to teach Classical Arabic but the Fransciscan remained in the post only for two years as he died in the summer of $1807 . .^{96}$

Early in October Grassi was appointed to teach Arabic at the University. However, the function of the Chair of Arabic had become a purely formal academic activity and the teaching post had no links with missionary activities in the Levant or North Africa. Reforms in the structure of the University of Malta in 1838 meant that the teaching of Arabic ended. Grassi lost his post and was forced to retire although he might have continued to teach Arabic, rather irregularly and unofficially, at the Lyceum (the Boys Grammar School established after the expulsion of the Jesuits). ${ }^{97}$ What is certain is that the teaching of Arabic did not terminate with Grassi's loss of his post. A Lebanese Maronite turned Protestant, Ahmad Faris al-Shidyaq, became the new lecturer of Arabic at the Lyceum and the Valletta Government Elementary School. Nevertheless, al-Shidyaq did not stay long and he resigned a mere three years after his appointment. ${ }^{98}$ The post of Professor of Arabic and Oriental

\footnotetext{
94 ASPF, SC, I, ff. 328v-329.

95 Bishop Labini had appointed the priest Fr Angelo Palma as bursar. Palma died in 1807, the year of Mgr Labini's demise. On 24 November, 1807 the Archdeacon and Vicar of the Cathedral Chapter, Giuseppe Bartholomeo Xerri, proposed the appointment of Canon Salvatore Abela instead of Palma. Letter addressed to Cardinal Michele di Pietro, Prefect of Propaganda Fide, ASPF, SC, I, ff. 356-357.

96 The date of Fr Anastasio's demise is given by Agius as 20 August 1807. Agius, discovered a necrology of Fr Anastasio at the Archives of the Franciscan Province of Malta., Misc. B p. 27, cf. Agius, Malta, Centru ghat-Taghlim ta' l-Gharbi, p. 16.

${ }_{97}$ Agius, Malta, Centru ghat-Taghlim ta' l-Gharbi, pp. 16-17.

98 Ahmad Faris al-Shidyaq had originally entered the service of Protestant missionaries, who sent him to Malta in 1826. In Malta he was employed by the English Church Missionary Society (CMS), served as assistant at the Arabic press and was in constant touch with the British Arabists Thomas Jarrett and Thomas Robinson, who, with the Society for Promoting Christian Knowledge, directed the Arabic printing press. He finally left Malta in 1848 and spent most of the next ten years in Europe, first in England, mainly in Cambridge and later Oxford where he prepared and saw through the press a new Arabic translation of the Bible. He became a British subject in 1851 but eventually left for Paris where he published his famous autobiographical and literary work Al-Saq 'aid 'l-saq in 1855 . He moved to Tunis in 1857 where he became Muslim and in 1860 left for Istanbul to work as a journalist. The following year he started an Arabic
} 
Languages was next offered to Roberto Casolani who taught Arabic, both at the University and the Lyceum, for a few years until he obtained permission to leave Malta temporarily in 1853 when the vacant post was offered to Gaetano Ciancio. Ciancio remained in the post from 23 June 1853 to 23 September 1858. In a letter he sent from Istanbul on 10 September Casolani informed the British authorities in Malta that he wished to relinquish his post. Ciancio remained in his position until 1881 when Casolani returned to Malta and took up his previous post until 1889 . When Casolani finally retired, the post of teacher of Arabic at the Lyceum, was offered to Antonio Sarreo. ${ }^{99}$

The teaching of Arabic at University had again fallen into abeyance. Sarreo taught Arabic until 1895 when the Maronite Lebanese priest Yusuf Sebhlani took over as teacher of Arabic at the Lyceum. Sebhlani remained in Malta, teaching Arabic, until the outbreak of the First World War in 1914-15. Very poor attendance for Arabic classes by Maltese students, and the great financial strain generated by the Great War may have induced the British Colonial Government of Malta to consider the classes as economically unfeasible. The post of Arabic became redundant and the class shut.

\section{Concluding remarks}

The insistence over the centuries on retaining the teaching of Arabic in Malta confirms that despite the island's geographical peripheral position in the European scene, Malta gained value in the eyes of the Catholic Church largely thanks to the presence of the Order of St John and its perpetual crusade against Islam. Nevertheless, the dominant factor in Rome's policy was the powerful issue of language. The idea that Malta's proximity to the Levant, and the similarity of the native Maltese language to Arabic, was shared by several religious orders, particularly the Jesuits, the Franciscans, and Discalced Carmelites.

newspaper there, Al-Jawa'ib. The newspaper gained a wide circulation in the Arab world and beyond, and brought him great fame as a writer and journalist. By 1870 he established in Istanbul the Jawa'ib Press and published many classical Arabic literary texts, philological works and other writings including semi-official Ottoman publications. By the time of his death in 1887 he had established a reputation as one of the foremost Arabic writers of the nineteenth century. A detailed account on the work of al-Shidyaq can be found in Roper, Geoffrey J., "Arabic Printing in Malta 1825-1845: Its History and Its Place in the Development of Print Culture in the Arab Middle East", Unpublished PhD Dissertation, University of Durham, 1988. See also Agius, Malta, Centru ghat-Taghlim ta' l-Gharbi, p. 20.

99 Cremona, "Lantica fondazione della scuola di lingua araba in Malta", 1/2, p. 101; Agius, Malta, Centru ghat-Taghlim ta' l-Gharbi, pp. 20-1. 
The Jesuit authorities in particular chose to 'privilege' Malta as an ideal base for the evangelization of the Levant. Similarly, the Congregation of Propaganda Fide in Rome felt the need to 'privilege' Malta for the same reason. More importantly, they strongly believed that Malta was ideally suited to help bring the Levantine Christians closer to Rome.

In essence, the original idea behind the teaching of Arabic in Malta was based on the belief that Malta could serve as a base for the missionaries destined for the Levant. Influential prelates, like Inquisitor Fabio Chigi, who considered the Maltese to be the only Catholic Christians who spoke Arabic, spearheaded the idea. Several influential prelates made every possible effort to convince the Holy See to encourage the Maltese to learn how to read and write the language. ${ }^{100}$ Despite the vicissitudes of the school of Arabic, and the general lack of genuine interest of the Maltese in the study of the language, the Congregation remained steadfast throughout the centuries in its conviction that Malta was ideally suited for the teaching of Arabic. Thus, the idea that associated the teaching of Arabic with Christian missions to the Levant continued to hold until the end of the eighteenth century. In the early nineteenth century, under British colonial rule, Arabic remained on the list of subjects taught at the University of Malta and was later introduced at the Lyceum and the Valletta Government School. The British colonial authorities may even have encouraged its teaching.

Despite the continuity and application by the authorities, including the involvement of several distinguished academics, Arabic was never a popular choice. The closure of the post in Arabic coincided with the outbreak of the First World War. The British colonial government claimed it had decided to make some budget cuts, which was probably true. At face value, one may associate the Arabic language with the Middle East and thus the Ottoman empire, which had sided with the Axis during the War. Yet there may have been other issues at play. We know that for several decades, the British government tried to encourage the Maltese to settle in other parts of the empire, but all its attempts failed and the majority of migrants had to return. ${ }^{101} \mathrm{~A}$ census of 1911 shows that the majority of Maltese migrants were still seeking other Mediterranean cities and ports, notably Tunis, Alexandria, Bône, Cairo,

100 See note 46 above. BAV Chigi A.I.4, ff. 214v-215. Chigi to Barberini: 15 May, 1637. Cf. Gambin, "Fabio Chigi", pp. 199-200. Chigi was later elected pope as Alexander VII (1655-67).

101 Price, Charles A., Malta and the Maltese. A Study in Nineteenth-Century Migration (Melbourne; Georgian House, 1954), p. 8; Cutajar, Dominic, "The lure of the Orient: the Schranzes, the Brockdorffs, Preziosi and other artists", Hyphen (Malta) 5/3 (1987), p. 133. 
Philippeville, Tripoli, Corfu, and Istanbul. This may suggest that despite their reluctance to study Arabic, the Maltese felt at ease among Arabic speakers, and possibly Ottomans. Whatever the case, it is clear that up to the First World War, many Maltese migrants remained in the Mediterranean where they formed relatively large communities until well after the end of the Second World War. These territories, with the exception of Corfu, had originally all belonged to the Ottomans. Some of the most popular destinations - Tunis, Bône, Philippeville - were French. Italy had just conquered Tripoli (1912), and Corfu was part of Greece. Only Alexandria and Cairo in Egypt were under some form of British control. It may explain why the British did their utmost to convince the Maltese to migrate to the British Dominions. That became possible only after the political turmoil caused by the Second World War. ${ }^{102}$

Finally, the end of Arabic teaching coincided with the emergence of the belief that the Maltese descended from the Phoenicians whose language they had preserved over the millennia. Lord Gerald Strickland (1861-1940), then leader of the Pro-British Constitutional Party, pushed this idea, which he had borrowed from the eighteenth century Maltese linguist and folklorist Canon Agius De Soldanis (1712-70). ${ }^{103}$ Unlike De Soldanis, Strickland was a shrewd politician who wished to introduce the teaching of Maltese and English at the expense of Italian. Strickland argued that both languages were necessary for the amelioration of working class conditions and went so far as to postulate that the Maltese were descended from the Phoenicians. ${ }^{104}$ By associating the Maltese with the ancient Phoenicians Strickland was simply saying that the Maltese might have had Semitic origins but that did not mean they were Arabs. Evidently, by suppressing the Arabic origins of Maltese to propagate a Phoenician ancestry, Strickland had struck a politically 'correct' balance that

${ }^{102}$ A good number of Maltese left for the USA, Canada, Britain, Australia and other Englishspeaking countries after World War Two. Migration reached a climax between 1948 and 1966 when it rarely fell below the 5,000 mark annually which is significant when the total population of the Maltese Islands was around 300,000. See especially Attard, Lawrence E., Early Maltese Migration 1900-1914 (Malta: Gulf, 1983); Zammit, Edward L., A Colonial Inheritance. Maltese Perceptions of Work, Power and Class Structure with Reference to the Labour Movement (Malta: Malta University Press, 1984), p. 19.

103 De Soldanis, Agius, Della lingua punica presentemente usata dai maltesi... ovvero nuovi documenti li quali possono servire di lume all'antica lingua etrusca... (Rome: 1750); National Library of Malta, Library Ms. 144 ("Nuova sculoa dell'antica lingua punica scoperta nel moderno parlar maltese e gozitano, del Canonico Gian Francesco Agius (De Soldanis)").

${ }_{104}$ Strickland, Gerald, Malta and the Phoenicians (Malta: Empire Press, 1920), pp. 7-8, 12,25 . 
suited all sectors of the population. In the early twentieth-century Maltese mindset, an Arabic heritage was synonymous with Muslim civilization, a culture that had no place in any prototype of 'Christian Europe'. Strickland had no choice. If he wished to please the Maltese electorate, he had to suppress the Arabic grass roots of the Maltese language and propagate a Phoenician ancestry for the Maltese people. In such circumstances, Arabic had no place in Malta. 